\title{
STUDY OF PHASE TRANSFORMATIONS IN COMPLEX PHASE STEEL USING A MESOSCALE CELLULAR AUTOMATON MODEL PART II: EXPERIMENTS AND VALIDATION
}

\author{
BADANIA PRZEMIAN FAZOWYCH W STALI WIELOFAZOWEJ ZA POMOCA \\ MEZOSKALOWEGO MODELU AUTOMATU KOMÓRKOWEGO \\ CZĘŚĆ II: : EKSPERYMENTY I WALIDACJA
}

A two-dimensional mesoscale model based on the concept of hybrid cellular automata was used to study phase transformations in a complex phase steel during continuous cooling. This model enables simulation of the decomposition of austenite into ferrite, bainite, and martensite, accompanied by calculations of volume and grain boundary diffusion of carbon. In effect, as a result, one can observe the morphology of simulated microstructures, corresponding carbon segregation as well as microhardness distribution. These results with the kinetics of austenite to ferrite phase transformation and predicted values of the complex phase steel hardness are the subject of model validation. A series of dilatometric experiments were carried out with constant cooling rates in order to construct a CCT diagram and validate the presented model. The convergence of simulated results with empirical outcomes was confirmed quantitatively using a dedicated goal function and data summaries in the table and graphs. However, some qualitative and quantitative discrepancies in terms of microstructure morphology are indicated which was possible thanks to applying a wide range of different validation parameters of the model. It is emphasized how crucial is the use of appropriate validation methodology.

Keywords: phase transformations, complex phase steel, cellular automata, mesoscale model, dilatometry, microstructure characterization, model validation
Dwuwymiarowy mezoskalowy model oparty na koncepcji hybrydowych automatów komórkowych zastosowano do badania przemian fazowych $w$ stali wielofazowej podczas ciagłego chtodzenia. Model ten umożliwia symulację rozpadu austenitu $w$ ferryt, bainit i martenzyt wraz z obliczeniami objętościowej i granicznej dyfuzji wegla. W efekcie można zaobserwować morfologie symulowanych mikrostruktur, odpowiadajaca im segregacje wegla, a także rozktad mikrotwardości. Wyniki te wraz z kinetyka ferrytycznej przemiany fazowej i przewidywanymi wartościami twardości stali wielofazowej sa przedmiotem walidacji modelu. Przeprowadzono szereg eksperymentów dylatometrycznych przy statych szybkościach chtodzenia w celu opracowania wykresu CTPc i walidacji przedstawionego modelu. Zbieżność wyników symulacji z danymi empirycznymi została potwierdzona ilościowo za pomoca dedykowanej funkcji celu oraz zestawienia danych $w$ tabeli i na wykresach. Jednakize, wskazano na pewne rozbieżności jakościowe i ilościowe pod względem morfologii mikrostruktury, co byto możliwe dzięki zastosowaniu szerokiego wachlarza różnych parametrów do walidacji modelu. Podkreślono, jak istotne jest zastosowanie odpowiedniej metodologii walidacji.

Stowa kluczowe: przemiany fazowe, stal wielofazowa, automaty komórkowe, model mezoskalowy, dylatometria, charakterystyka mikrostruktury, walidacja modelu

\section{INTRODUCTION}

There is still a need to improve and develop new materials for the automotive industry with a focus on such important features as safety, fuel efficiency, environmentalism, manufacturability, durability, and quality while minimizing the lifetime greenhouse gas emissions from production, use, and end-of-life phases of the vehicle [1]. Therefore, the global steel industry continuing the improvement and optimization of process production of steels dedicated to the automobile's construction. To fulfill the diverse performance requirements of vehicle components exten- sive scope of advanced high strength steels (AHSS) with unique properties has been developed. Notwithstanding, there exists a broad set of capabilities to ameliorate properties of the already developed steel grades, for instance as shown in the works [2-4]. This process is also supported by research using computer modeling of microstructural phenomena in a virtual space, such as numerical technological processes simulations accounting for phase transformations at the mesoscale level [5-8].

Nevertheless, the used assumptions to build a numerical model of phase transformations need to be verified and the simulation results confirmed by experiments. Therefore, one of the crucial aspects of mesoscale models develop- 
ment is their validation to prove their efficiency. In a lot of works [6-15] concerning the cellular automata (CA) models of phase transformations, their qualitative and quantitative validation using experimental data is presented. In a few works [7, 8, 10-12] the simulation results were validated quantitatively based on the kinetics of phase transformations, which is extremely valuable information for the verifying modeling assumptions. On the other hand, only in some works [6-10, 13-15], authors validated their developed CA models qualitatively based on direct comparison of simulated microstructures in the form of a digital material representation (DMR) with metallographic images from microstructural studies using LOM or SEM techniques. However, there is a lack of examples in the literature concerning the quantitative validation of simulated microstructures using stereological methods and parameters characterizing their morphology.

In this work, a physically-based mesoscale model from our previous work [16] about the acronym CAFD2D-SSPT (i.e. Cellular Automata and Finite Difference methods in $2 D$ for Solid State Phase Transformations) is used to perform numerical experiments of continuous cooling of the complex phase (CP) steel with the phase transformations of austenite into ferrite, bainite, and martensite. The goal of this paper is to present the validation methodology of the mesoscale model simulation results using experimental data. In order to validate the proposed CAFD2D-SSPT model, a series of dilatometric experiments were carried out with constant cooling rates, which subsequently were analyzed with qualitative and quantitative methods. Next, the samples were investigated using optical microscopy and scanning electron microscopy. The obtained metallographic pictures were quantitatively analyzed using stereological methods. Subsequently, the kinetics of ferrite phase transformation, hardness, as well as stereological parameters of experimental and simulated microstructures were compared. The intention was to highlight the significance and need to apply different validation methods, which could indicate the good accuracy as well as misaligning of results obtained with physically-based discrete models of phase transformations at solid-state.

\section{MATERIAL, EXPERIMENTAL PROCEDURE, AND RESULTS}

\subsection{MATERIAL DESCRIPTION}

The chemical composition of the investigated CP steel is listed in Table 1. The material was produced in industrial conditions as a steel strip, and therefore the steel is signed as CP-IH (Complex Phase - Industrial Heat). The steel strip was cold-rolled with a $65 \%$ total degree of deformation and was supplied to the laboratory in the form of a sheet with a thickness of $0.9 \mathrm{~mm}$ and dimensions $100 \mathrm{~mm} \times 100 \mathrm{~mm}$.

\subsection{SCOPE AND METHODOLOGY}

Dilatometry was used for the experimental study of the phase transformations utilizing a Bähr dilatometer DIL 805 $\mathrm{A} / \mathrm{D}$, dedicated to quenching experiments. The steel sam- ples used for the different thermal cycles executed in dilatometry were prepared with an atypical flat shape (cuboid) and dimensions: $0.9 \mathrm{~mm} \times 1 \mathrm{~mm} \times 7 \mathrm{~mm}$, which was imposed by the geometry of the supplied industrial material. In order to construct the CCT diagram, the continuous cooling tests were performed. The dilatometric specimens were first heated with an average rate of $3^{\circ} \mathrm{C} / \mathrm{s}$ from room temperature to the austenitizing temperature of $857^{\circ} \mathrm{C}$. Next, the samples were immediately cooled to room temperature with a series of controlled continuous cooling rates in the range from $0.5^{\circ} \mathrm{C} / \mathrm{s}$ to about $409^{\circ} \mathrm{C} / \mathrm{s}$. However, for cooling rates higher than $100^{\circ} \mathrm{C} / \mathrm{s}$, the quenching dilatometer was not able to follow the programmed temperature-time course with high precision. Therefore the cooling rates $207^{\circ} \mathrm{C} / \mathrm{s}$ and $409^{\circ} \mathrm{C} / \mathrm{s}$ did not remain constant in the whole range of the thermal cycle. The temperature-time courses of experiments are presented in Fig. 1.

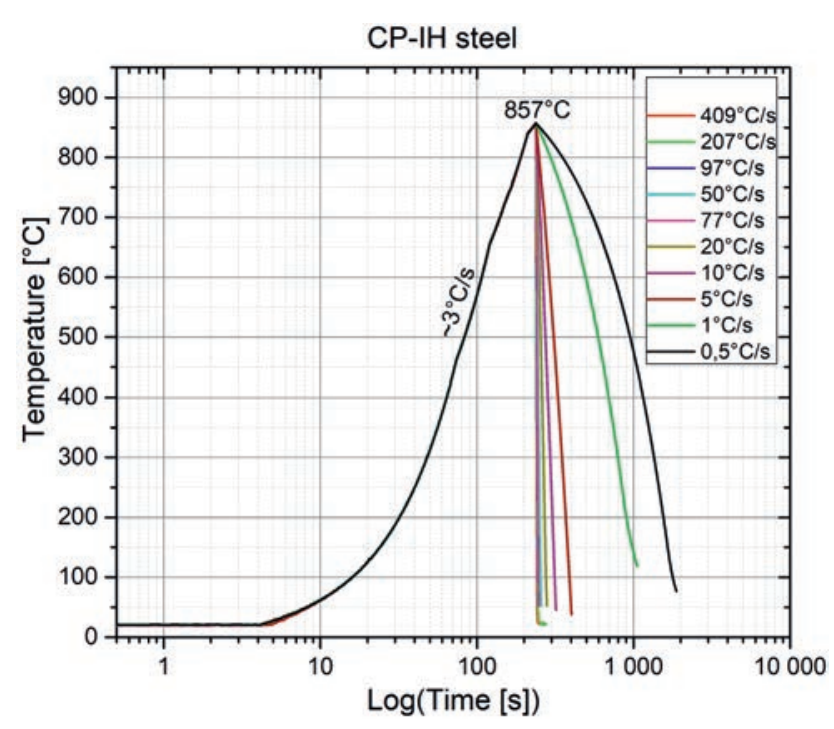

Fig. 1. Temperature-time courses of dilatometric experiments Rys. 1. Przebiegi temperaturowo-czasowe eksperymentów dylatometrycznych

The resulting hardness of the dilatometry specimens was characterized by Vickers hardness (HV) tests and microstructures were analyzed using light optical microscopy (LOM) and scanning electron microscopy (SEM). The analysis was carried out in the middle of the length of the dilatometric specimens, where the controlling thermocouple was welded, to ensure that the microstructure observations were consistent with the dilatometry measurements. LOM analysis was performed on an OLYMPUS DSX500i optical digital microscope and SEM investigations were carried out using an INSPECT F high-resolution scanning microscope with a field emission gun. Hardness measurement was taken using a Vickers HTM 1839 hardness tester with a load of $4.9 \mathrm{~N}$ (HV0.5).

The microstructure from the experiment with the highest cooling rate $\left(409^{\circ} \mathrm{C} / \mathrm{s}\right)$ was used to determine the initial austenite microstructure and grain size. To establish the grain boundaries of the prior austenite and grain size

Table 1. Chemical composition of the investigated steel CP-IH, [wt. \%] Tabela 1. Skład chemiczny stali w gatunku CP-IH, [\% wag.]

\begin{tabular}{|c|c|c|c|c|c|c|c|c|c|c|}
\hline Steel & C & Si & Mn & Cr & Ni & Mo & Cu & Al & P & S \\
\hline $\mathrm{CP}-\mathrm{IH}$ & 0.155 & 0.389 & 1.531 & 0.225 & 0.031 & 0.004 & 0.015 & 0.039 & 0.009 & 0.002 \\
\hline
\end{tabular}


a methodology presented in work [17] was used. Furthermore, for microstructures from all experiments, the volume fraction of structural constituents was estimated by quantitative metallography. A graphical software GIMP [18] was used to mark and outline structures in the form of the raster image. It means that each structural constituent is represented by a different color, which is exemplified in the next section with the results. However, in further image analysis (IA), each structural component was investigated separately using a binary format. Next, the resultant binary images were used to quantitative characterization of the microstructures applying advanced analytical techniques with a Met-Ilo program [19], as in the work of Radwański et al. [20].

Critical temperatures of the austenite transformation on heating and austenite decomposition on continuous cooling were determined from dilatometric curves using the tangential extrapolation method in the dilatation curve and its corresponding first derivative. Analyses were carried out in accordance with the guidelines included in works [21, 22]. Furthermore, the dilatometric curves were quantitatively analyzed using a methodology presented in associated publications $[17,23]$. In effect, there was possible to determine directly volume fraction changes of the austenite phase transformations' products as a function of time and temperature.

\subsection{DILATOMETRIC AND MICROSTRUCTURE INVESTIGATION RESULTS}

In Fig. 2 the experimental CCT diagram for the investigated CP-IH steel is presented. It was constructed based on the analyses of the dilatometric curves from experiments performed with continuous cooling rates. The series of cooling curves are plotted from the austenitizing temperature of $857^{\circ} \mathrm{C}$, together with the Vickers hardness results measured for cooling rates between 50 and $409^{\circ} \mathrm{C} / \mathrm{s}$. The start and finish transformation temperatures of each structural constituent are assigned and the corresponding points are connected resulting in the construction of the CCT diagram. In consequence, four regions matching to the new products of austenite (A) decomposition are revealed, i.e. ferrite $(\mathrm{F})$, pearlite $(\mathrm{P})$, bainite $(\mathrm{B})$, and martensite (M). The occurrence of reported phase transformations' products was verified by metallographic characterization.

According to the experimental CCT diagram of Fig. 2, the first transformation product of the austenite decomposition is ferrite, which takes place in the range of all cooling rates. However, for the highest cooling rate (about $409^{\circ} \mathrm{C} / \mathrm{s}$ ), the austenite to ferrite transformation has the lowest contribution and the bainite transformation dominates. A small proportion of ferrite and martensite phases are created, which was confirmed by the metallographic investigation. Furthermore, ferrite was formed only at the grain boundaries of the prior austenite in the form of fine grains. In effect, for the obtained microstructure with the highest cooling rate, it was possible to recognize and point out the grain boundaries of the former austenite. For the other cooling rates, ferrite transformation has prevailed and a volume fraction of ferrite observed in the steel microstructures is not less than 29\%. Therefore, from the validation of the developed CAFD2D-SSPT model point of view the phase transformations' range visible on the CCT diagram is favorable. Since the simulations of phase transformations at the mesoscale using the CAFD2D-SSPT model mainly depend on the model formulation for the first diffusional transformation product of the austenite. It is related to the effect of the increase in carbon content in the residual austenite during ferrite formation, which strongly influences the start temperatures and character of the

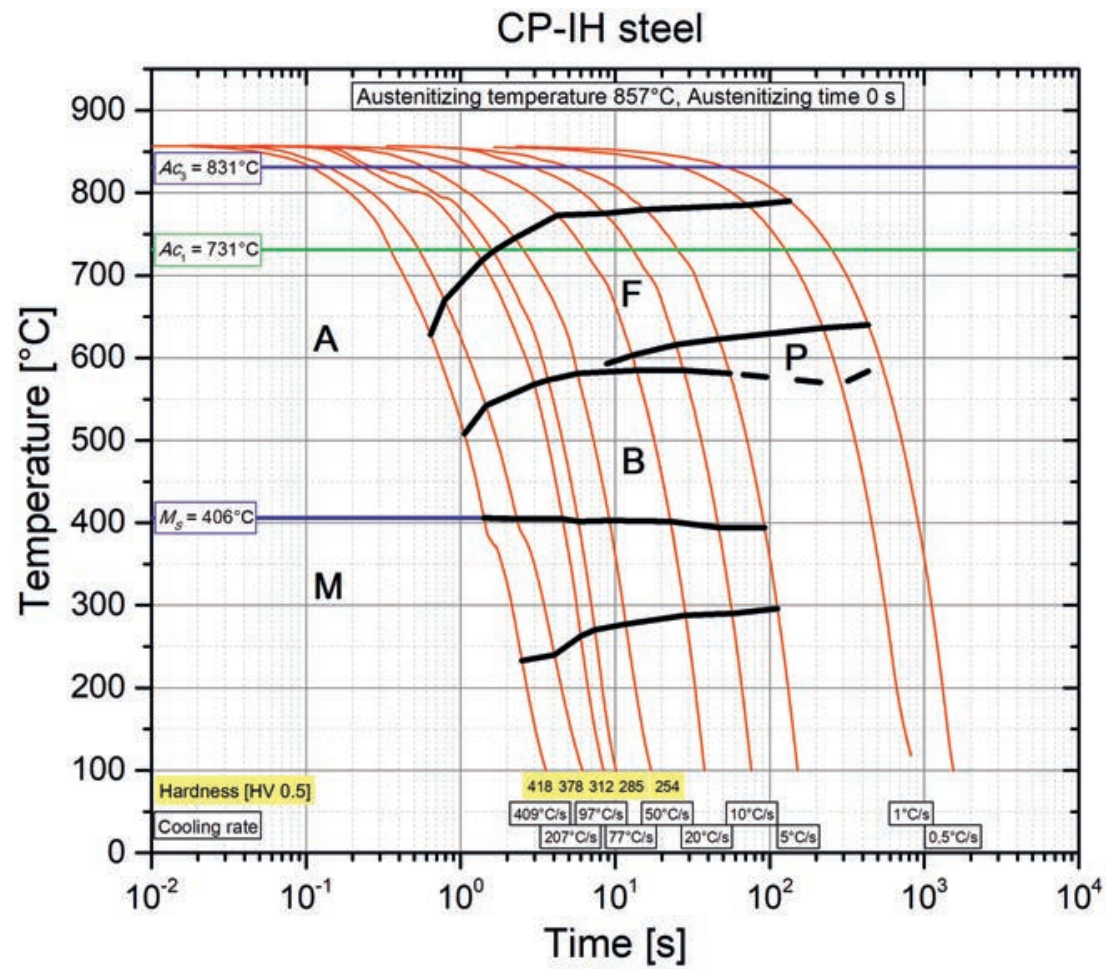

Fig. 2. Experimental continuous cooling transformation (CCT) diagram for CP-IH steel, determined from the analysis of the dilatometry curves in continuous cooling from the temperature $857^{\circ} \mathrm{C}$

Rys. 2. Wykres eksperymentalny czas temperatura przemiana (CTPC) dla stali CP-IH, wyznaczony na podstawie analizy krzywych dylatometrycznych przy ciagłym chłodzeniu od temperatury $857^{\circ} \mathrm{C}$ 

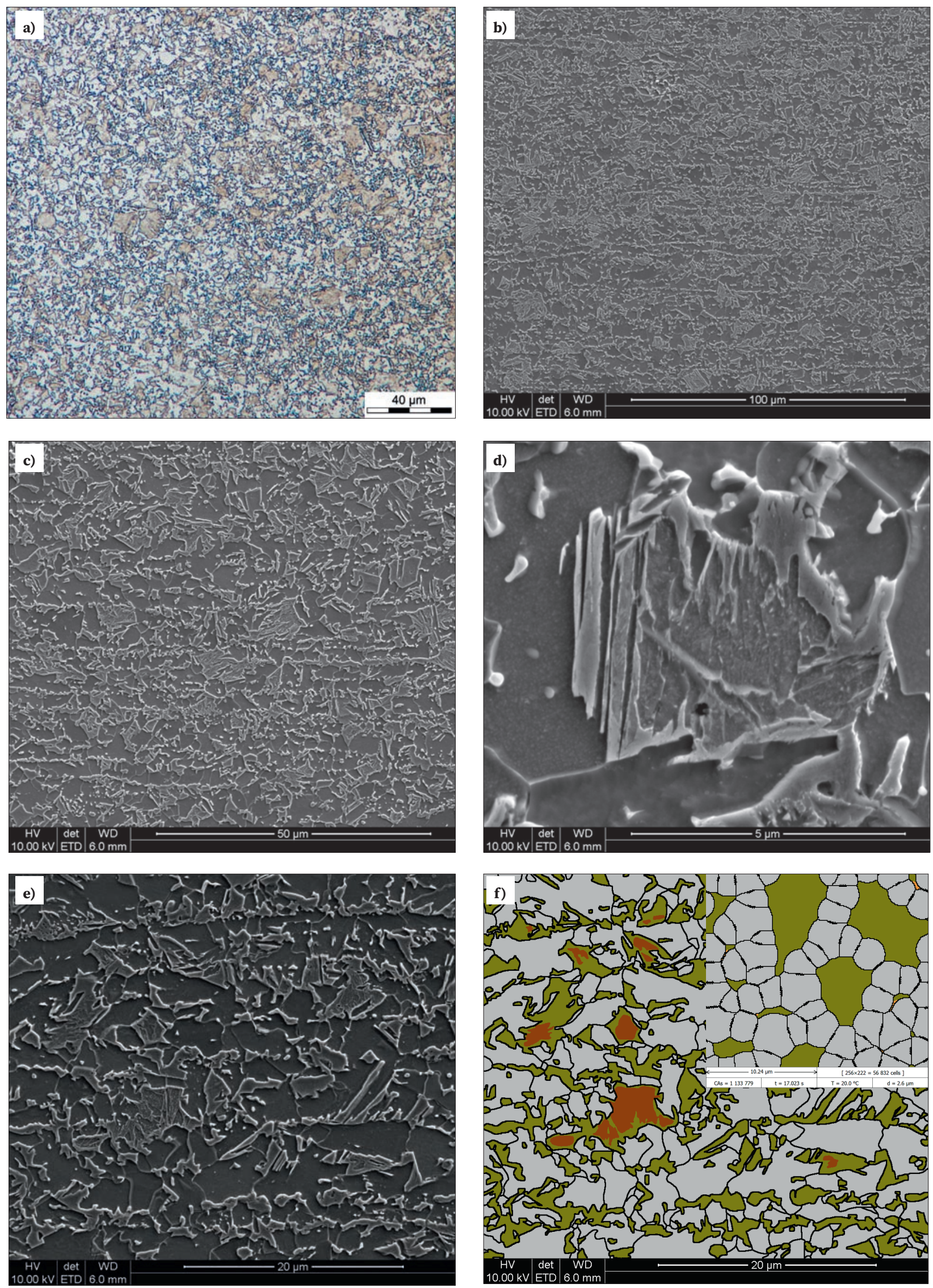

Fig. 3. Examples of microstructure images at different magnifications obtained with the help of LOM (a) and SEM (b, c, d, e) for a dilatometric sample cooled with rate $50^{\circ} \mathrm{C} / \mathrm{s}$, and image (f) showing the outline of individual structural constituents present in the microstructure from image (e). (Ferrite - is grey, Bainite - brown, Martensite - olive)

Rys. 3. Przykładowe obrazy mikrostruktury przy różnych powiększeniach uzyskane za pomocą LOM (a) oraz SEM (b, c, d, e) dla próbki dylatometrycznej chłodzonej z szybkością $50^{\circ} \mathrm{C} / \mathbf{s}$, a także obraz (f) przedstawiający obrys poszczególnych składników strukturalnych występujących w mikrostrukturze z obrazu (e). (Ferryt - kolor szary, Bainit - brązowy, Martenzyt - oliwkowy) 
other phase transformations of austenite. For cooling rates lower than $50^{\circ} \mathrm{C} / \mathrm{s}$ pearlitic transformation occurs. This transformation was not taken into account in the development of the CAFD2D-SSPT model. Therefore, only four dilatometric experiments with the occurrence of ferrite, bainite, and martensite transformations were considered in further analyses, i.e. with the following cooling rates: $50^{\circ} \mathrm{C} / \mathrm{s}, 77^{\circ} \mathrm{C} / \mathrm{s}, 97^{\circ} \mathrm{C} / \mathrm{s}$ and $207^{\circ} \mathrm{C} / \mathrm{s}$. For selected cooling rates quantitative dilatometric analyses were performed. The obtained results in the form of ferrite phase transformation kinetics were presented later and used in the validation of the physically-based CAFD2D-SSPT model.

Based on the instructions formulated in work [17] the qualitative and quantitative analyses of metallographic images from the LOM and SEM studies were realized. In effect, the structural constituents as ferrite, bainite, and martensite were identified and described in the investigated dilatometric samples. In order to determine the volume fraction of structural constituents in microstructures, a quantitative image analyses were performed using the Met-Ilo program [19]. Exemplary microstructures of a dilatometric sample cooled at a rate of $50^{\circ} \mathrm{C} / \mathrm{s}$ are shown in Fig. 3 at different magnifications. A raster image corresponding to the microstructure from Fig. 3.e) is presented in Fig. 3.f), on which structural constituents are depicted with different colors, i.e. grey, brown, and olive, respectively for ferrite, bainite, and martensite. Furthermore, for the quantitative assessment of the microstructure topology selected stereological parameters were applied. To characterize ferrite grains in each analyzed dilatometric sample stereological parameters such as mean equivalent diameter, elongation index, and shape index were used. The detailed results of the quantitative image analysis of microstructures are presented in the next sections with the validation results of the CAFD2D-SSPT model. Additionally in Fig. 3f) in the right top corner a simulated microstructure is imposed, which is discussed in detail later.

\section{SIMULATION SETTINGS}

The simulated material is the CP-IH steel which is characterized in detail in Section 2.1. In the computer simulations only the cooling curves with rates $50^{\circ} \mathrm{C} / \mathrm{s}, 77^{\circ} \mathrm{C} / \mathrm{s}$, $97^{\circ} \mathrm{C} / \mathrm{s}$, and $207^{\circ} \mathrm{C} / \mathrm{s}$ were implemented (see Fig. 2). The temperature-time cooling curves used in simulations were directly copied from experimental measurements, which are presented in Fig. 1. This research is intended to present and validate the numerical modeling results of the phase transformations of austenite into ferrite, bainite, and martensite, which were obtained with the CAFD2D-SSPT model. Accordingly, to perform exact numerical simulations of phase transformations the initial microstructure of the investigated $\mathrm{CP}-\mathrm{IH}$ steel is required. To replicate the starting microstructure a DMR approach proposed by Opara and Wrożyna [24] is adopted here based on SEM metallographic picture. The virtual microstructure is initialized as polycrystalline austenite phase with a homogenous carbon concentration equal to average content in the alloy (i.e. $0.155 \mathrm{wt}$. \%), and with various orientations of grains. The calculation domain with periodic boundary conditions is defined by a two-dimensional $256 \times 222$ square grid of cellular automata, representing a physical area of $20.48 \times 17.76 \mu \mathrm{m}^{2}$. For more detailed information about modeling assumptions and simulation key parameters, the reader is referred to the previous related paper [16].

\section{VALIDATION RESULTS AND DISCUSSION}

To comprehensively validate the modeling results a direct visual comparison between simulated microstructures and SEM metallographic pictures with corresponding raster images is presented in Fig. 4 and also in Fig. 3e, and Fig. 3f. The simulated results indicate that the morphological features of the microstructures are qualitatively consistent only to some extent with the observations of individual components of the structure in a real material. Especially in Fig. 4d, the morphology of ferrite grains differs considerably between simulated and SEM investigated microstructures. In the simulated microstructure, ferrite grains take more globular shapes, and there is a lack of other forms such as narrow and elongated grains. Furthermore, grains in simulated microstructures are much more regular and their interphase boundaries are smooth without any disturbed line segments. These morphological inconsistencies are also quantitatively captured in stereological analysis results with insightful parameters such as the aspect ratio and shape index, which is presented later in Fig. $5 \mathrm{a}$ and Fig. $5 \mathrm{~b}$. The discrepancies in comparison of the microstructures are mainly caused by the assumption of isotropic and homogenous conditions in the CAFD2D-SSPT model with respect to the substructure and chemical composition of the initial microstructure into simulations. In contrast, in a real material heterogeneous chemical elements distribution, impurities and anisotropic substructure is present, which locally affect the kinetics of phase transformations and microstructure's morphology, and in consequence the mechanical properties of the alloy. Such an effect is documented inter alia in works of Springer et al. [25], He and Huang [26], in which strong influence of chemical elements distribution in initial microstructures on the progress of further phase transformations was observed.

In relation to the qualitative investigations of microstructures, quantitative research was also carried out, which results are presented in Fig. 5. In this case the CAFD2DSSPT model validation relied on the use of stereological parameters to characterize the morphology of microstructures from simulations as well as from SEM investigations of the dilatometric samples. Fig. 5 presents, in the form of column charts, a summary of selected stereological parameters characterizing ferrite grains in microstructures after physical and numerical experiments of continuous cooling with the following rates: $50^{\circ} \mathrm{C} / \mathrm{s}, 77^{\circ} \mathrm{C} / \mathrm{s}, 97^{\circ} \mathrm{C} / \mathrm{s}$ and $207^{\circ} \mathrm{C} / \mathrm{s}$. As can be seen in Fig. $5 \mathrm{a}$ and Fig. $5 \mathrm{~b}$, the values of the aspect ratio and shape index of ferrite grains from images of digital material representation differ considerably from the values of these parameters describing grains from the investigated microstructures using SEM, except experiment with a cooling rate of $207^{\circ} \mathrm{C} / \mathrm{s}$ for which almost excellent convergence was obtained. It can be explained by the fact that grain boundary diffusion of carbon along austenite GB's dominates in such undercooling which was additionally intensified by adjusting the highest mobility factor for this case $\left(M_{\gamma \rightarrow \alpha}^{\text {eff }}=450 \mathrm{~mol} \cdot \mathrm{m} \cdot \mathrm{J}^{-1} \cdot \mathrm{s}^{-1}\right)$. More details about this fitting parameter one can find in the previous related work [16]. Therefore ferrite grains in the structure have elongated shapes along the austenite grain boundaries which is thoroughly exemplified in Fig. $4 \mathrm{f}$ (right top 

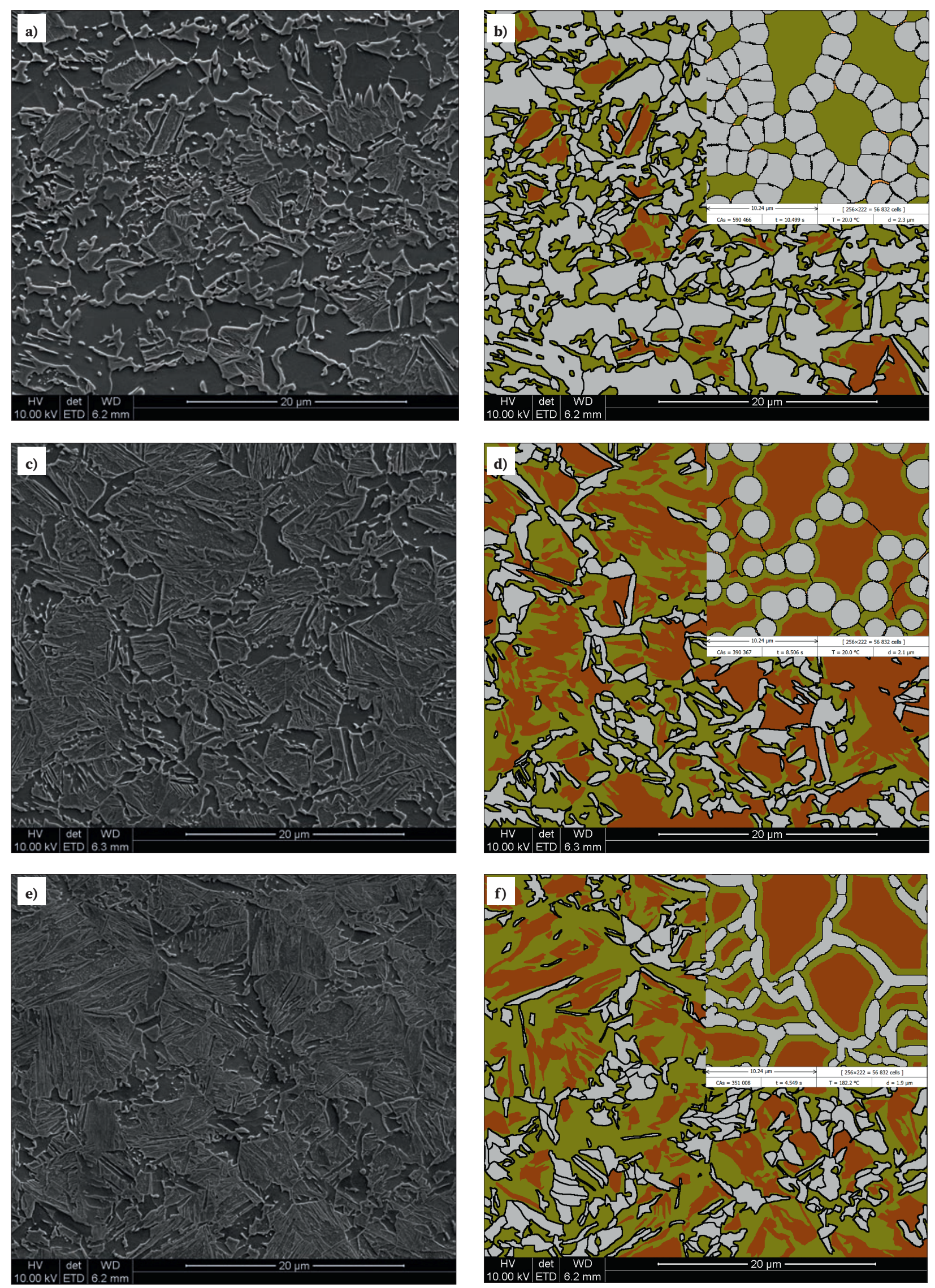

Fig. 4. Comparison of microstructures after continuous cooling experiments at rates of $77^{\circ} \mathrm{C} / \mathrm{s}(\mathrm{a}, \mathrm{b}), 97^{\circ} \mathrm{C} / \mathrm{s}(\mathrm{c}, \mathrm{d})$ and $207^{\circ} \mathrm{C} / \mathrm{s}(\mathrm{e}, \mathrm{f})$, which are derived from the scanning electron microscopy investigations (left), its metallographic image analyses (right), and from the simulations (in the right top corner). In the colored micrographs, the ferrite is grey, bainite is brown, and martensite is olive

Rys. 4. Porównanie mikrostruktur po ciagłych eksperymentach chłodzenia z szybkościami $77^{\circ} \mathrm{C} / \mathrm{s}(\mathrm{a}, \mathrm{b}), 97^{\circ} \mathrm{C} / \mathrm{s}(\mathrm{c}, \mathrm{d})$ and $207^{\circ} \mathrm{C} / \mathrm{s}(\mathrm{e}, \mathrm{f}), \mathrm{które}$ pochodzą z badań na skaningowym mikroskopie elektronowym (po lewej), metalograficznych analiz obrazu (po prawej) i symulacji numerycznych (w prawym górnym narożniku). Na kolorowych mikrografiach ferryt jest szary, bainit brązowy, a martenzyt oliwkowy 

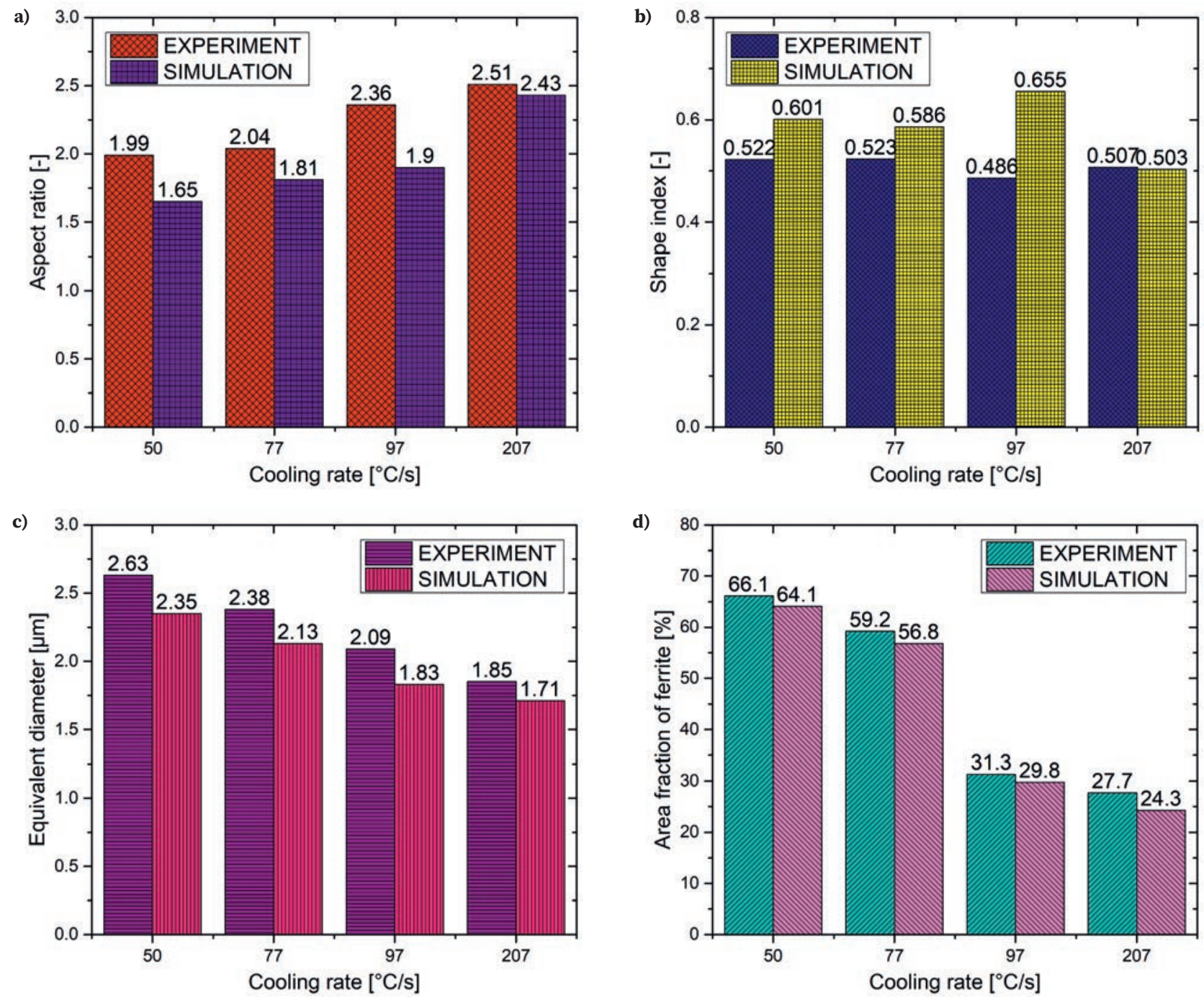

Fig. 5. Summary of results in the form of selected stereological parameters characterizing ferrite grains in microstructures from simulations and dilatometric samples after continuous cooling experiments at rates $50^{\circ} \mathrm{C} / \mathrm{s}, 77^{\circ} \mathrm{C} / \mathrm{s}, 97^{\circ} \mathrm{C} / \mathrm{s}$ and $207^{\circ} \mathrm{C} / \mathrm{s}$, where: (a) aspect ratio; $(\mathrm{b})$ shape index; (c) equivalent diameter of ferrite grain; (d) area fraction of ferrite

Rys. 5. Zestawienie wyników $w$ formie wybranych parametrów stereologicznych charakteryzujących ziarna ferrytu w mikrostrukturach z symulacji oraz próbek dylatometrycznych po eksperymentach ciąłłego chłodzenia z szybkościami $50^{\circ} \mathrm{C} / \mathrm{s}, 77^{\circ} \mathrm{C} / \mathrm{s}, 97^{\circ} \mathrm{C} / \mathrm{s}$ i $207^{\circ} \mathrm{C} / \mathrm{s}$, gdzie: (a) wskaźnik wydłużenia; (b) wskaźnik kształtu; (c) średnia średnica ziarna ferrytu; (d) udział powierzchniowy ferrytu

corner with DMR microstructure). For an experiment with a such high cooling rate $\left(207^{\circ} \mathrm{C} / \mathrm{s}\right)$ the influence of substitutional elements is negligible. In other cases, the ferrite grain aspect ratio from DMR's indicates that the shapes of these grains are less elongated than ferrite grains found in metallographic images. Whereas, the shape index points out that the ferrite grains in the digital material representation of the microstructure take more globular forms. Although the results from the numerical simulations show an upward trend in the aspect ratio along with the increase in the cooling rate (Fig. 5a), as for empirical data, it is difficult to consider this result as satisfactory. As was highlighted previously, the discrepancies in the detailed characteristics of ferrite grain morphology, which are depicted in the digital material representation, are primarily due to the simplifications adopted in the developed CAFD2D-SSPT model. One of the reasons for this effect is the assumption of isotropic conditions for volume diffusion of carbon in the modeling space. The second is the determination of the homogeneous distribution of carbon concentration in the initial microstructure of DMR. Another reason is probably the omission of modeling the impact of phenomena related to the substructure, e.g. carbon diffusion across sub-grain boundaries, which results from an inadequate degree of discretization of the modeling area to include such subtle elements of the microstructure. Furthermore, taking into account the redistribution of manganese in the initial microstructure of DMR would allow the introduction of a banding effect in the material, which could affect the directional growth of ferrite grains and lengthen their shape in one of the growth directions. This effect was artificially introduced in the CA model presented by Bos et al. [7], by establishing the $M n$ concentration profile in the digital material representation of microstructure. Although the $M n$ concentration profile was fixed as a function only of the $y$ position of a cell, it allows identifying the essential mechanisms of the band formation.

In contrast to the stereological indicators described earlier, for parameters characterizing ferrite grains less insightfully, such as the equivalent diameter and area fraction of ferrite, a satisfactory agreement was obtained between simulation results and empirical data. The values of the average equivalent diameter of ferrite grains from numerical simulations differ less than $0.3 \mu \mathrm{m}$ from the results of 
measurements of structures in the investigated material on SEM, as shown in Fig. 5c. Furthermore, the graph in Fig. 5c perfectly illustrates the effect of increasing the cooling rate on the refinement of ferrite grains, which equally reflect the results of numerical simulations.

The image analysis' results in the form of the area fraction of ferrite from simulations and experiments are presented in Fig. 5d. The highest absolute error (3.4\%) between results from both sources is obtained for the sample cooled with rate $207^{\circ} \mathrm{C} / \mathrm{s}$. For other cases the discrepancies are less than $2.5 \%$. Therefore, one can conclude that the simulation outcomes are consistent on a satisfactory level of compliance with the empirical data. It is worth noting that the area fraction of ferrite was determined for all $\mathrm{mi}-$ crostructures, i.e. from investigated microstructures on SEM and simulated microstructures in the CAFD2D-SSPT model, with the same image analysis procedures using the Met-Ilo software [19], in which the boundaries between grains and phases are not included in the calculations because only grain areas are taken into account in the analyzes to characterize them.

Fig. 6 compares the graphs of ferritic transformation kinetics derived from numerical simulations, as well as quantitative analysis of dilatograms carried out using QDILAM computer software [23]. The kinetic of ferritic transformation was chosen for validation of simulation results, because it is a key phase transformation with diffusion character during cooling accompanied by segregation of carbon in the microstructure, and its course largely determines the further progress of phase transformations of the remaining austenite. For most simulated kinetics of ferrite depicted in Fig. 6, one can deduce that the ferrite nucleation is slower than for experimental results but the subsequent ferrite growth is much faster. The reverse situation takes place for experiment with the cooling rate of $207^{\circ} \mathrm{C} / \mathrm{s}$, which can be caused by the underestimation in the model of the ferrite start transformation temperature for undercooling below the $A c_{1}$ temperature. Moreover, one can observe that only the kinetics of the phase transfor-

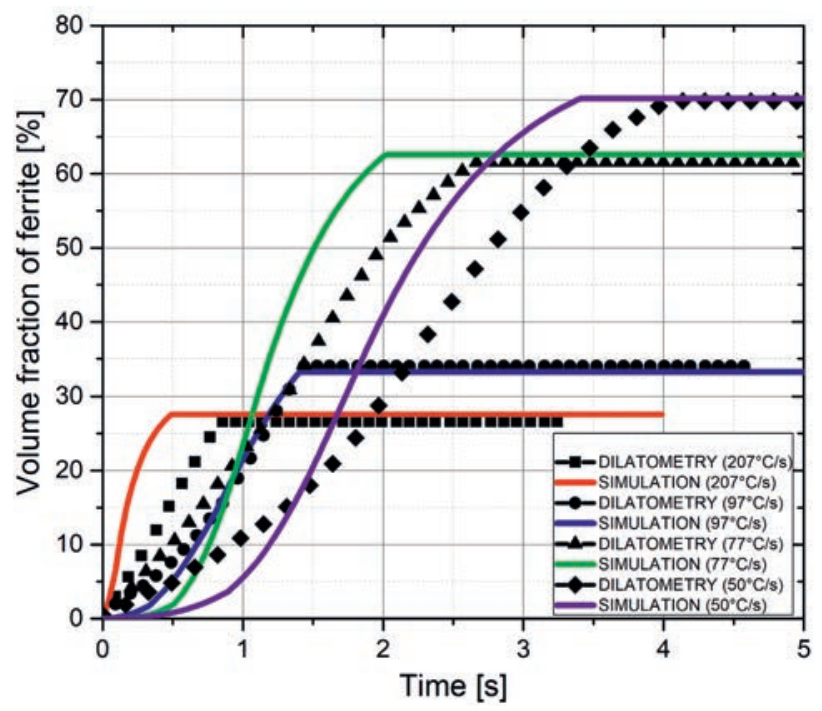

Fig. 6. Modeling results of phase transformation kinetics for $\mathrm{CP}-\mathrm{IH}$ steel from numerical experiments of continuous cooling at rates: (a) $50^{\circ} \mathrm{C} / \mathrm{s}$, (b) $77^{\circ} \mathrm{C} / \mathrm{s}$, (c) $97^{\circ} \mathrm{C} / \mathrm{s}$, (d) $207^{\circ} \mathrm{C} / \mathrm{s}$

Rys. 6. Wyniki modelowania kinetyki przemian fazowych dla stali CP-IH z numerycznych eksperymentów ciagłego chłodzenia z szybkościami: (a) $50^{\circ} \mathrm{C} / \mathrm{s}$, (b) $77^{\circ} \mathrm{C} / \mathrm{s}$, (c) $97^{\circ} \mathrm{C} / \mathrm{s}$, (d) $207^{\circ} \mathrm{C} / \mathrm{s}$ mation for an experiment performed with a cooling rate of $97^{\circ} \mathrm{C} / \mathrm{s}$ on a good level of compliance throughout the ferrite growth range coincides with the course of analytical studies. Other kinetic curves obtained in simulations strongly deviate from experimental courses and stabilize about half-second earlier but at almost the same level of the final value of the ferrite volume fraction. For this reason, it can be concluded that the presented simulation results in the form of kinetics are at an acceptable level of convergence with the empirical results. Nevertheless, probably a better fit could be obtained if the effective mobility of the interface $\left(M_{\gamma \rightarrow \alpha}^{\text {eff }}\right)$ would be varied as a function of undercooling as was proposed by Gamsjäger et al. [27].

The results presented in Fig. 7 allows to assess the effect of undercooling, at various cooling rates, on the ferrite volume fraction course of changes as a function of temperature, and to which extent the numerical simulations reflect this effect. Similarly as in case of the analysis of the ferritic transformation kinetics from the numerical experiment of continuous cooling at a rate of $97^{\circ} \mathrm{C} / \mathrm{s}$, so likewise for the case of the ferrite volume fraction changes as a function of temperature, the best convergence of curves from simulation and the analytical investigation was obtained at this cooling rate (see Fig. 7). For the first three cooling rates of $50^{\circ} \mathrm{C} / \mathrm{s}, 77^{\circ} \mathrm{C} / \mathrm{s}, 97^{\circ} \mathrm{C} / \mathrm{s}$, a satisfactory result was obtained of matching the values of the ferritic transformation start temperature to the empirical data, which are presented in Fig. 7. Whereas, the least accurate of simulation results in terms of matching the ferritic transformation start temperature and the curves of the ferrite volume fraction changes as a function of time and temperature were obtained for a continuous cooling experiment at a rate of $207^{\circ} \mathrm{C} / \mathrm{s}$. This is because, at this cooling rate, the transformation of austenite into ferrite begins at significant undercooling, several dozen degrees below the $A c_{1}$ and $A e_{1}$ temperatures, which means that the thermodynamic conditions at the phase transformations' front are far from equilibrium. Therefore, solving Stefan's problem may introduce additional underestimation of growth kinetics. Furthermore, the partial

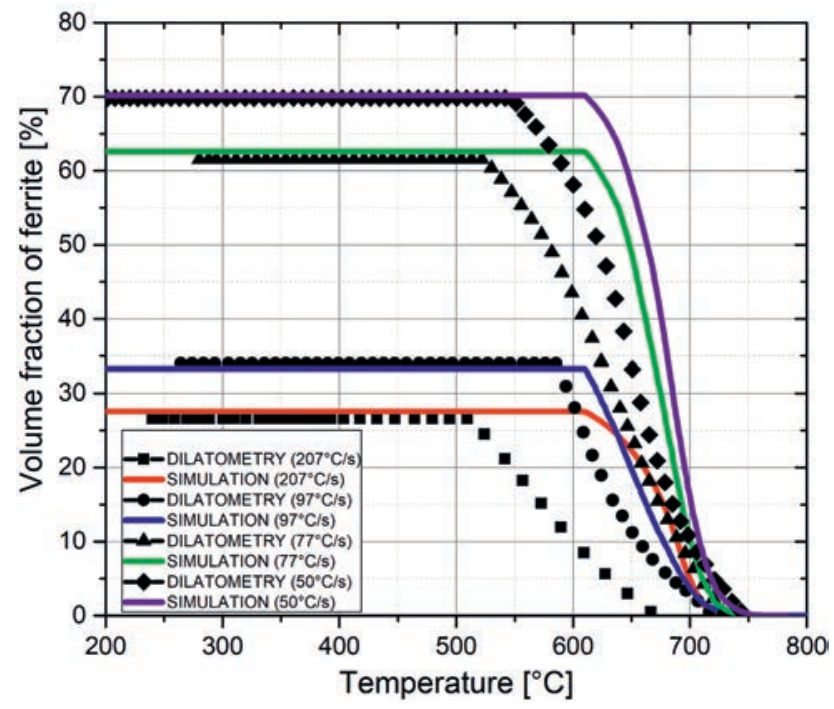

Fig. 7. Modeling results of volume fractions changes of individual microstructural constituents as a function of temperature for CP-IH steel from numerical experiments of continuous cooling at rates: (a) $50^{\circ} \mathrm{C} / \mathrm{s}$, (b) $77^{\circ} \mathrm{C} / \mathrm{s}$, (c) $97^{\circ} \mathrm{C} / \mathrm{s}$, (d) $207^{\circ} \mathrm{C} / \mathrm{s}$

Rys. 7. Wyniki modelowania zmian ułamków objętości poszczególnych składników struktury w funkcji temperatury dla stali CP-IH z numerycznych eksperymentów ciagłego chłodzenia z szybkościami: (a) $50^{\circ} \mathrm{C} / \mathrm{s}$, (b) $77^{\circ} \mathrm{C} / \mathrm{s}$, (c) $97^{\circ} \mathrm{C} / \mathrm{s}$, (d) $207^{\circ} \mathrm{C} / \mathrm{s}$ 
model of ferrite nucleation, in this case, underestimates the undercooling value below the $A c_{1}$ temperature.

In order to accurately validate the results of numerical simulations (see Fig. 8), the final volume fractions of structural components were compared with the results of analytical investigations, which were obtained from two sources. The first source is the results of the quantitative characterization of structures obtained based on metallographic studies, followed by the quantitative image analyses of microstructure using the Met-Ilo software [19]. It was assumed that the results of the quantitative assessment of structures in the form of area fractions are equivalent to the values of volume fractions. The second source is originating data from quantitative analyses of dilatometric curves conducted with QDILAM computer software [23], which in the form of kinetics are presented in Fig. 6 . Where the last values of kinetics define the final composition of the microstructure after the completion of phase transformations.

It is necessary to explain that the presented results of ferrite volume fractions obtained in the kinetics simulations

a)

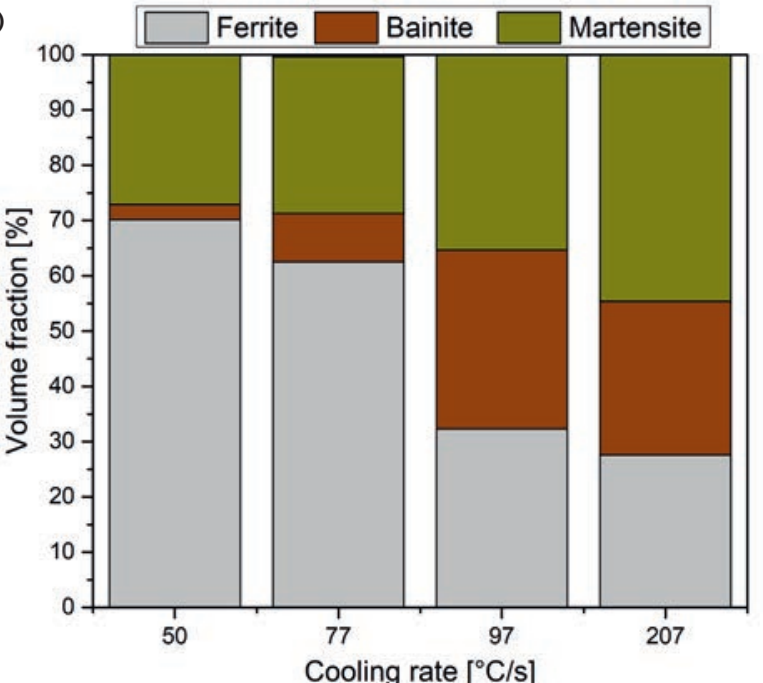

c)

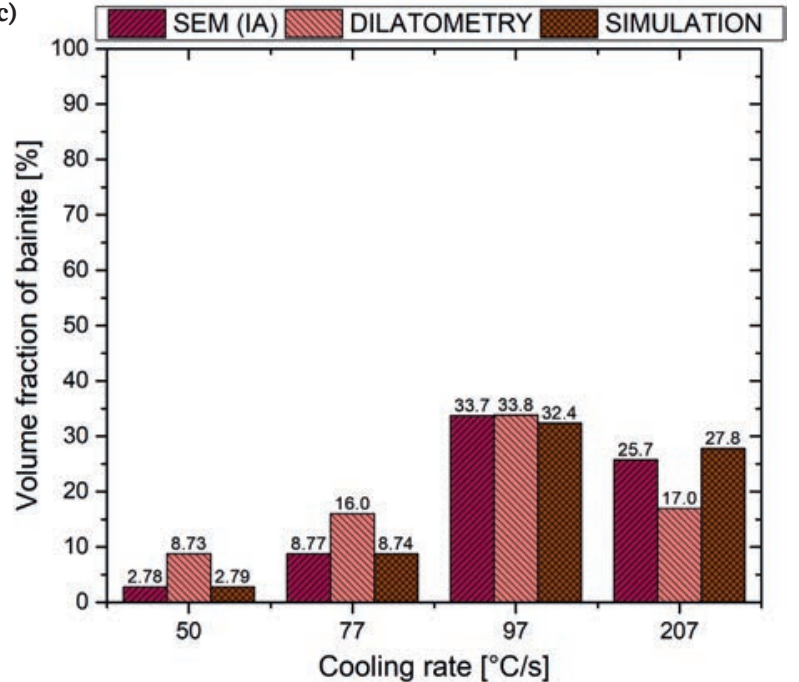

using the CAFD2D-SSPT model are divergent with the outcomes from simulated microstructures (DMR) image analysis using the Met-Ilo software [19] (compare results from Fig. 5d and Fig. 8b), because of the method to calculate ferrite volume fraction. In the CAFD2D-SSPT model calculations of ferrite volume fractions relies on summation of the values of ferrite fractions both from cellular automata representing interior of ferrite grains and additionally included interphase boundaries. Similar inconsistency applies to the experimental results presented in Fig. 5d and Fig. $8 \mathrm{~b}$, because ferrite volume fractions in the latter are calculated from the difference between the residual area fraction and determined area fractions of bainite and martensite, so that grain boundaries and interfaces are included in the calculations of the overall volume fraction of ferrite. It is reasonable approach, because obtained results from numerical simulations and microstructure investigations on SEM can be directly compared with outcomes from the quantitative dilatograms' analyses, in which the dilatation effect comes both from physical changes in the interior of grains, interphase and grain boundaries. b)

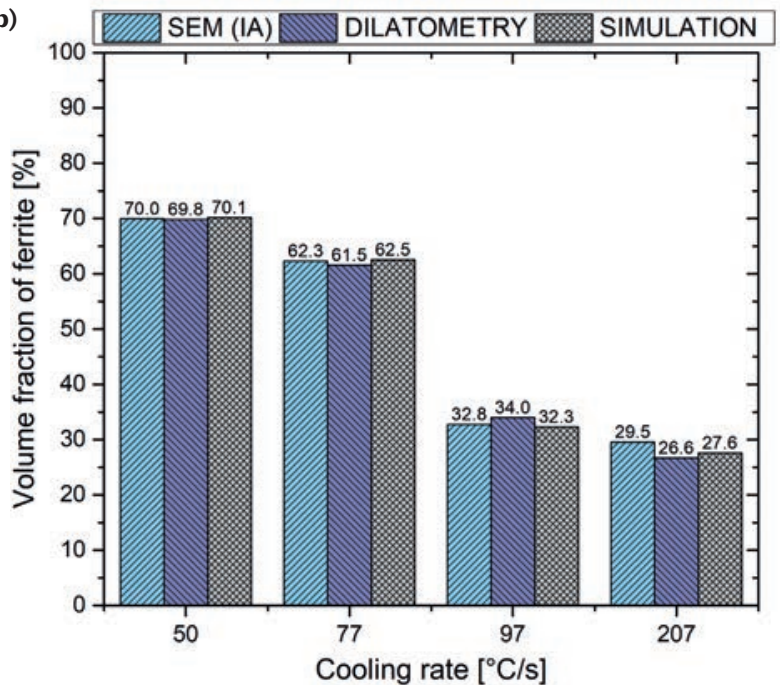

d)

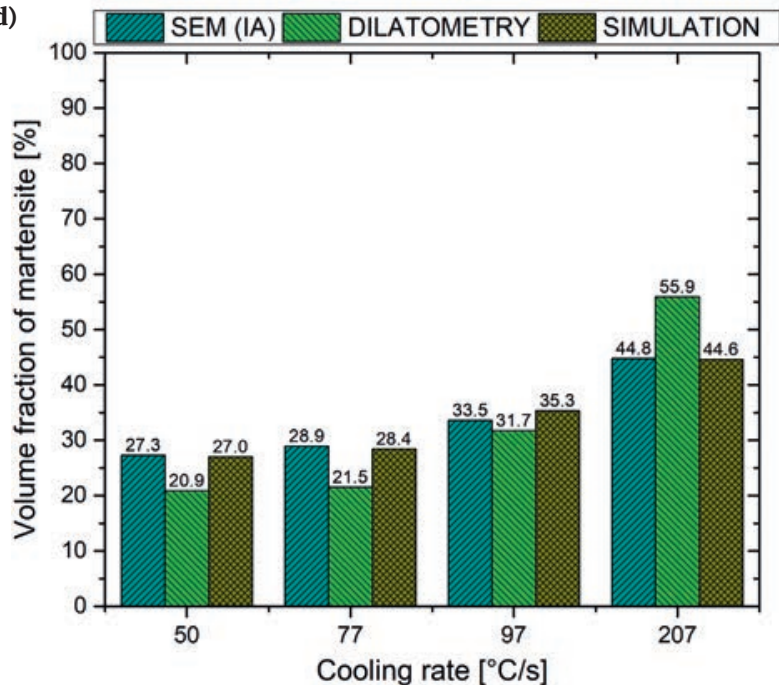

Fig. 8. Simulation results of final volume fractions of individual components of the structure (a) in CP-IH steel after continuous cooling experiments at different rates and their comparison with results of image analysis of SEM micrographs and quantitative dilatograms analysis, separately for: ferrite (b), bainite (c) and martensite (d)

Rys. 8. Wyniki symulacji końcowych ułamków objętościowych poszczególnych składników struktury (a) w stali CP-IH po eksperymentach ciągłego chłodzenia z różnymi szybkościami oraz ich porównanie z rezultatami analizy obrazów mikrografii z SEM oraz ilościowej analizy dylatogramów, osobno dla: ferrytu (b), bainitu (c) i martenzytu (d) 
Fig. 8a presents in the columnar diagram the results of volume fractions of individual structural components, which were obtained after numerical cooling experiments at the rates of $50^{\circ} \mathrm{C} / \mathrm{s}, 77^{\circ} \mathrm{C} / \mathrm{s}, 97^{\circ} \mathrm{C} / \mathrm{s}$ and $207^{\circ} \mathrm{C} / \mathrm{s}$. In Fig. 8 a one can observe a downward trend in the ferrite volume fraction as the cooling rate increases. Whereas, the volume fractions of other austenite transformation products increases. A more detailed comparison of the volume fractions' values is presented in Fig. 8b, Fig. 8c and Fig. 8d, respectively for ferrite, bainite, and martensite. It can be seen in Fig. $8 \mathrm{~b}$ that the final ferrite volume fractions from the simulations for all used cooling rates differ slightly from the empirical results within $2 \%$ range of absolute values, which can be considered as a satisfactory level of convergence. The best concurrence of the ferrite volume fractions was obtained for a numerical experiment carried out at a cooling rate of $50^{\circ} \mathrm{C} / \mathrm{s}$, in which the absolute difference between the simulation result and the quantitative analysis of the dilatogram was $0.3 \%$. Moreover, compared to the result of quantitative structure analysis, this difference was only $0.2 \%$.

In the case of volume fractions of bainite and martensite, the obtained convergence between the simulation outcomes and the results of quantitative characterization of structures using IA procedures in Met-Ilo, similarly as for the ferrite volume fractions, were in the range up to $2 \%$ of absolute values, as is shown in the column charts in Fig. 8c and Fig. 8d. In turn, the largest discrepancies between simulation results and empirical data were obtained when compared with the outcomes of quantitative dilatogram analysis (QDILAM) for the most cooling rates, except $97^{\circ} \mathrm{C} / \mathrm{s}$, where the differences between the volume fractions of individual structural components were in the range of $6 \%$ to $11.3 \%$. However, it should be emphasized that the results of the quantitative characterization of structures using IA are more reliable because they result from direct observation of the state of the microstructure. On this basis, it can be concluded that the volume fractions of bainite and martensite obtained in numerical simulations are at a satisfactory level of compliance with empirical results.

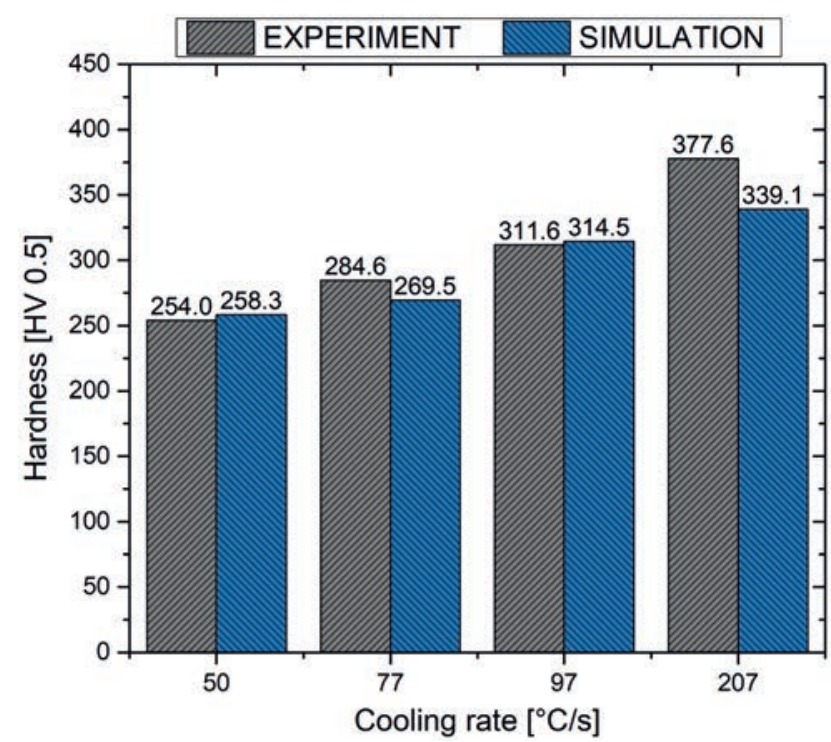

Fig. 9. Comparison of the modeling and measurement results of hardness in the dilatometric samples from experiments of continuous cooling at rates: $50^{\circ} \mathrm{C} / \mathrm{s}, 77^{\circ} \mathrm{C} / \mathrm{s}, 97^{\circ} \mathrm{C} / \mathrm{s}, 207^{\circ} \mathrm{C} / \mathrm{s}$

Rys. 9. Zestawienie wyników modelowania oraz pomiarów twardości próbek dylatometrycznych z eksperymentów ciągłego chłodzenia z szybkościami: $50^{\circ} \mathrm{C} / \mathrm{s}, 77^{\circ} \mathrm{C} / \mathrm{s}, 97^{\circ} \mathrm{C} / \mathrm{s}$ i $207^{\circ} \mathrm{C} / \mathrm{s}$
Another crucial aspect of the CAFD2D-SSPT model validation was a comparison of the calculated hardness values from the numerical simulations with the results of hardness measurements performed on dilatometric samples. The column chart in Fig. 9 presents a summary of the hardness results obtained from measurements and modeling. For continuous cooling experiments with rates $50^{\circ} \mathrm{C} / \mathrm{s}, 77^{\circ} \mathrm{C} / \mathrm{s}$, and $97^{\circ} \mathrm{C} / \mathrm{s}$, the absolute hardness differences between the measurement and simulation results are only about $15 \mathrm{HV}$. However, at a cooling rate of $207^{\circ} \mathrm{C} / \mathrm{s}$, this difference increases to $38 \mathrm{HV}$. Nevertheless, it can be concluded that the results of the hardness modeling of the virtual microstructures are at a good level of convergence to empirical data. The presented hardness modeling results confirm the generally known conclusion that faster cooling leads to an increase in steel hardness.

Fig. 10 depicts the estimated values of the mechanical properties of the investigated CP-IH steel based on corresponding equations presented in the previous related paper [16]. As one can observe with an increase in the cooling rate the highest mechanical properties are obtained, which directly follows from their linear relationship with the average hardness of the steel (see Fig. 9). Unfortunately, the presented results cannot be validated due to lack of experimental data, because it is not possible to measure mechanical properties on the dilatometry samples using a standard tensile test. Nevertheless, the presented results in Fig. 10 show the capabilities of the CAFD2D-SSPT model, which next can be considered in the computer design of AHSS steels.

Furthermore, detailed analyses were performed in order to more precisely validate the simulation results. The crucial parameters describing the ferrite phase transformation and the final state of the microstructure were chosen for quantitative assessment of the results because they mainly decide about the mechanical properties of the steel. Namely, the six following parameters were used, i.e. the start temperature of the ferritic transformation $\left(T_{F_{S}}\right)$, the average equivalent diameter of ferrite grain $\left(d_{\alpha}\right)$,

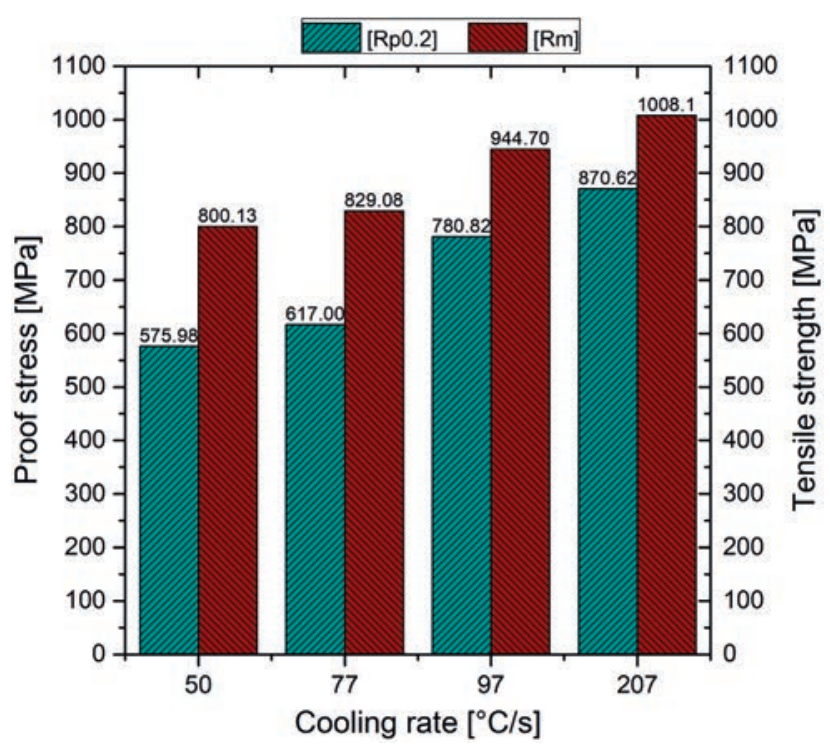

Fig. 10. Estimation results of mechanical properties from numerical experiments of continuous cooling at rates: $50^{\circ} \mathrm{C} / \mathrm{s}, 77^{\circ} \mathrm{C} / \mathrm{s}, 97^{\circ} \mathrm{C} / \mathrm{s}$, $207^{\circ} \mathrm{C} / \mathrm{s}$

Rys. 10. Wyniki oszacowania właściwości mechanicznych z numerycznych eksperymentów ciąłłego chłodzenia z szybkościami: $50^{\circ} \mathrm{C} / \mathrm{s}$, $77^{\circ} \mathrm{C} / \mathrm{s}, 97^{\circ} \mathrm{C} / \mathrm{s}$ i $207^{\circ} \mathrm{C} / \mathrm{s}$ 
Table 2. Comparison of chosen crucial parameters from experiments and simulations Tabela 2. Porównanie wybranych kluczowych parametrów z eksperymentów i symulacji

\begin{tabular}{|c|c|c|c|c|c|c|}
\hline \multirow{2}{*}{ Data } & \multirow{2}{*}{ Parameter } & \multirow{2}{*}{ Unit } & \multicolumn{4}{|c|}{ Cooling rates } \\
\hline & & & $50^{\circ} \mathrm{C} / \mathrm{s}$ & $77^{\circ} \mathrm{C} / \mathrm{s}$ & $97^{\circ} \mathrm{C} / \mathrm{s}$ & $207^{\circ} \mathrm{C} / \mathrm{s}$ \\
\hline \multirow{6}{*}{ EXPERIMENT } & $T_{F_{S}}$ & ${ }^{\circ} \mathrm{C}$ & 745 & 729 & 718 & 670 \\
\hline & $d_{\alpha}$ & $\mu \mathrm{m}$ & 2.6 & 2.4 & 2.1 & 1.9 \\
\hline & $V_{\alpha}$ & $\%$ & 69.95 & 62.30 & 32.75 & 29.51 \\
\hline & $V_{B}$ & $\%$ & 2.78 & 8.77 & 33.70 & 25.69 \\
\hline & $V_{M}$ & $\%$ & 27.27 & 28.93 & 33.55 & 44.80 \\
\hline & $H_{V}$ & $\mathrm{HV}$ & 254 & 285 & 312 & 378 \\
\hline \multirow{6}{*}{ SIMULATION } & $T_{F_{S}}$ & ${ }^{\circ} \mathrm{C}$ & 738 & 729 & 721 & 714 \\
\hline & $d_{\alpha}$ & $\mu \mathrm{m}$ & 2.6 & 2.3 & 2.1 & 1.9 \\
\hline & $V_{\alpha}$ & $\%$ & 70.15 & 62.55 & 32.27 & 27.56 \\
\hline & $V_{B}$ & $\%$ & 2.79 & 8.74 & 32.36 & 27.81 \\
\hline & $V_{M}$ & $\%$ & 26.97 & 28.39 & 35.31 & 44.63 \\
\hline & $H_{V}$ & $\mathrm{HV}$ & 258 & 270 & 314 & 339 \\
\hline GOAL FUNCTION & $\Phi$ & - & 0.010 & 0.027 & 0.028 & 0.067 \\
\hline
\end{tabular}

$$
\Phi=\sqrt{\frac{\left(\frac{T_{F_{s}}^{e}-T_{F_{s}}^{s}}{T_{F_{s}}^{e}}\right)^{2}+\left(\frac{d_{\alpha}^{e}-d_{\alpha}^{s}}{d_{\alpha}^{e}}\right)^{2}+\left(\frac{V_{\alpha}^{e}-V_{\alpha}^{s}}{V_{\alpha}^{e}}\right)^{2}+\left(\frac{V_{B}^{e}-V_{B}^{s}}{V_{B}^{e}}\right)^{2}+\left(\frac{V_{M}^{e}-V_{\alpha}^{s}}{V_{B}^{e}}\right)^{2}+\left(\frac{H_{V}^{e}-H_{V}^{s}}{H_{V}^{e}}\right)^{2}}{6}}
$$

volume fractions of ferrite $\left(V_{\alpha}\right)$, bainite $\left(V_{B}\right)$ and martensite $\left(V_{M}\right)$, average hardness of the microstructure $\left(H_{\mathrm{V}}\right)$. These parameters obtained from numerical simulations and experimental investigations are compared in Table 2.

For data from Table 2, a dedicated goal function was formulated, which enables us to quantitatively assess and validate the obtained results from numerical simulations for each cooling rate separately. This function is defined as a square root error between measured and calculated parameters considered to the model validation. A similar assumption is commonly used in the inverse analysis method [28], however, in this approach, the goal function is calculated for all experiments simultaneously. In the current analyses, the goal function is described by formula (1), where: $e$ and $s$ are superscripts describing parameters obtained from experiments and simulations, respectively. When the value of the goal function calculated with equation (1) is closer to zero, the simulation result is more convergent with the experimental data. In Table 2 one can see that the values of goal function for all cooling rates are smaller than 0.1, and for most of them are even less than 0.03 , which means that the convergence between the simulation results and the investigation outcomes is almost excellent for parameters chosen to the CAFD2D-SSPT model validation.

Based on the presented analyzes, one can conclude that very good agreement between simulated and empirical results presented in Table 2, does not guarantee a good consistency of model with experiment in terms of microstructure morphology, which were investigated using quantitative and qualitative methods. For example, for the experiment with a cooling rate of $97^{\circ} \mathrm{C} / \mathrm{s}$, a very good convergence of the hardness, kinetics and final phase volume fractions was obtained, while the worst match in terms of morphology and stereological parameters. And conversely, for the experiment with the cooling rate of $207^{\circ} \mathrm{C} / \mathrm{s}$, an excellent fit was received in terms of morphology and stereological parameters, and the worst coincidence of the hardness, kinetics and final phase volume fractions were obtained. This proves that the model is not perfect and needs to be improved for further applications. Especially the heterogeneous chemical composition of the initial microstructure should be taken into account in the simulations.

\section{CONCLUSIONS}

In this article, a two-dimensional mesoscale model based on the concept of hybrid cellular automata was used to study phase transformations in a CP steel during continuous cooling. This model enables simulation of the decomposition of austenite into ferrite, bainite, and martensite, accompanied by calculations of volume and grain boundary diffusion of carbon. In effect, as a result, one can observe the morphology of simulated microstructures, corresponding carbon segregation as well as microhardness distribution on the so-called maps with properties redistribution, which are depicted in our previous work [16]. These results with the kinetics of austenite to ferrite phase transformation and predicted values of the CP steel hardness are the subject of model validation.

A series of dilatometric experiments were carried out with constant cooling rates in order to construct the CCT diagram, select experiments without pearlite transformation, and next validate the CAFD2D-SSPT model. Comparing directly the simulation results with the experimental data, one can conclude that the model predicts the equivalent diameter of ferrite and its area fraction, as well as the volume fraction of structural constituents reasonably well, which are depicted respectively in Fig. 5c, Fig. 5d, and Fig. 8. The model exhibits also good agreement between forecast values of hardness and measurement results (see 
Fig. 9). Furthermore, the convergence of these simulated results with empirical outcomes was confirmed quantitatively in Table 2 using the dedicated goal function, which is defined in equation (1). The values of goal function for all considered experiments are smaller than 0.1 , and for most of them are even less than 0.03 , which proof the excellent convergence of the simulated results. The model also predicts qualitatively well the trend of ferrite grains refinement as well as increase of mechanical properties as a function of cooling rate, which is exemplified in Fig. 5c, Fig. 9, and Fig. 10, respectively.

Despite very good convergence of simulated and empirical results presented in Table 2, some quantitative and qualitative divergence can be detected, especially when more detailed investigation of microstructure morphology is performed. The assessment of microstructure morphology using the image analysis technique and stereological parameters such as aspect ratio and shape index of ferrite grains show that simulated microstructures are less consistent with the SEM micrographs (see in Fig. 5a and Fig. $5 b$ ) than using other criteria. For this reason, the use of more sophisticated techniques of microstructure morphology assessment is justified, so that one can exactly validate the simulation results in various ways. Furthermore, direct visual comparison between simulated microstructures and SEM micrographs as well corresponding raster images (see Fig. 3e and Fig. 3f, Fig. 4) reveal significant differences in morphology. It can be explained by the assumption of isotropic and homogenous conditions in the CAFD2D-SSPT model with respect to the substructure and chemical composition of the initial microstructure in the DMR. In effect, simulated microstructures contain ferrite grains with regular shapes, smooth interfaces, and there is a lack of other inhomogeneity forms of structure such as narrow and elongated grains. Therefore to improve the presented CA model heterogeneous conditions such that are present in the real material should be considered, in particular with respect to the chemical composition of the initial microstructure.

The comparison of the kinetic curves depicted in Fig. 6 and Fig. 7 also reveals some discrepancies between simu- lation and experiment results. Only the kinetic curve from the numerical experiment performed with a cooling rate of $97^{\circ} \mathrm{C} / \mathrm{s}$ has a good convergence with the result from analytical studies throughout the ferritic transformation. For the most simulations, the kinetic curves strongly deviate from experimental courses and stabilize about half-second earlier, however at the same level of the final ferrite volume fraction as in experiments. Therefore, one can conclude that the presented results of the kinetics are at the acceptable level of compliance.

In conclusion, the presented validation methodology of the developed CAFD2D-SSPT model reveals that the model needs to be improved, despite excellent convergence of the simulated results with empirical outcomes in some quantitative and qualitative aspects, because for other criteria the divergence between results is noticeable. This shows how important is to introduce different validation parameters that could indicate the good accuracy as well as misaligning of results obtained with physically-based discrete models of phase transformations at mesoscale like the described one in this work. Moreover, based on that there is a prospect to correct the model on the way of successive approximations. Then getting a good convergence of simulation and experiment results in all validation aspects will be possible.

Notwithstanding the drawbacks of the presented CAFD2D-SSPT model, after the introduction of several improvements especially heterogeneous conditions in the initial microstructure, it can be used as a tool, in the form of a computer program with a user-friendly interface, to design and analysis of optimal thermal cycles to produce multi-phase steels with the specified microstructure and phase composition. That can be a useful approach from the point of view of steel producers for the automotive industry.

\section{ACKNOWLEDGEMENTS \\ Financial assistance from the Research Fund for Coal and Steel, Grant Agreement number RFSR-CT-2011-00014, is acknowledged.}

\section{REFERENCES}

[1] Future Steel Vehicle. Final Engineering Report, Steel Market Development Institute, Washington, DC, 2011. [Online] Available at: www.autosteel.org [Accessed on 28 August 2020].

[2] J.G. Speer, D.K. Matlock, B.C. De Cooman, J.G. Schroth. Carbon partitioning into austenite after martensite transformation. Acta Materialia, 2003, 51, p. 2611-2622.

[3] H. Beladi, G.L. Kelly, A. Shokouhi, P.D. Hodgson. Effect of thermomechanical parameters on the critical strain for ultrafine ferrite formation through hot torsion testing. Materials Science and Engineering A, 2004, 367, p. 152-161.

[4] D.K. Matlock, J.G. Speer. Processing Opportunities for New Advanced High-Strength Sheet Steels. Materials and Manufacturing Processes, 2010, 25, p. 7-13.

[5] M.J. Santofimia, L. Zhao, J. Sietsma. Overview of Mechanisms Involved During the Quenching and Partitioning Process in Steels. Metallurgical and Materials Transactions A, 2011, 42, p. 3620-3626.

[6] C.W. Zheng, N. Xiao, L. Hao, D. Li, Y. Li. Numerical simulation of dynamic strain-induced austenite-ferrite transformation in a low carbon steel. Acta Materialia, 2009, 57 p. 2956-2968.

[7] M.G. Mecozzi, C. Bos, J. Sietsma. 3D cellular automata modelling of solid-state transformations relevant in low-alloy steel production. Solid State Phenomena, 2011, 172-174, p. 1140-1145.

[8] C. Bos, M.G. Mecozzi, D.N. Hanlon, M.P. Aarnts, J. Sietsma. Application of a Three-Dimensional Microstructure Evolution Model to Identify Key Process Settings for the Production of Dual-Phase Steels. Metallurgical and Materials Transactions A, 2011, 42, p. 36023610.

[9] L. Zhang, C.B. Zhang, Y.M. Wang, S.Q. Wang, H.Q. Ye. A cellular automaton investigation of the transformation from austenite to ferrite during continuous cooling. Acta Materialia, 2003, 51, p. 5519-5527.

[10] S. Kundu, M. Dutta, S. Ganguly, S. Chandra. Prediction of phase transformation and microstructure in steel using cellular automaton technique. Scripta Materialia, 2004, 50, p. 891-895.

[11] Y.J. Lan, D.Z. Li, Y.Y. Li. Modeling austenite decomposition into ferrite at different cooling rate in low-carbon steel with cellular automaton method. Acta Materialia, 2004, 52, p. 1721-1729.

[12] B.J. Yang, L. Chuzhoy, M.L. Johnson. Modeling of reaustenitization of hypoeutectoid steels with cellular automaton method. Computational Materials Science, 2007, 41, p. 186-194.

[13] C.W. Zheng, D. Raabe. Interaction between recrystallization and phase transformation during intercritical annealing in a coldrolled dual-phase steel: A cellular automaton model. Acta Materialia, 2013, 61, p. 5504-5517.

[14] C.W. Zheng, D. Raabe, D.Z. Li. Prediction of post-dynamic austenite-to-ferrite transformation and reverse transformation in a low-carbon steel by cellular automaton modeling. Acta Materialia, 2012, 60, p. 4768-4779. 
[15] D. An, S. Pan, L. Huang, T. Dai, B. Krakauer, M. Zhu. Modeling of Ferrite-Austenite Phase Transformation Using a Cellular Automaton Model. ISIJ International, 2014, 54, p. 422-429.

[16] J. Opara, R. Kuziak. Study of phase transformations in a complex phase steel using a mesoscale cellular automaton model. Part I: Modeling Fundamentals. Journal of Metallic Materials, 2020, 73 (3), p. 17-31.

[17] J. Opara, W. Zalecki. Dilatometric and metallographic research for the verification of phase transformations mesoscale model. Prace Instytutu Metalurgii Żelaza, 2018, 70 (3), p. 32-39.

[18] The GIMP Development Team. GIMP, 2019 [Online]. Available at: https://www.gimp.org.

[19] J. Szala. Met-Ilo v12.1 - instruction manual. Katowice, 2009. [unpublished].

[20] K. Radwański, A. Wrożyna, R. Kuziak. Role of the advanced microstructures characterization in modeling of mechanical properties of AHSS steels. Materials Science and Engineering A, 2015, 639, p. 567-574.

[21] Stahl-Eisen-Prüfblatt. 1681, Guidelines for preparation, execution and evaluation of dilatometric transformation test on iron alloys, STAHL-EISEN-Prüfblätter (SEP) des Vereins Deutscher Eisenhüttenleute, Issue 2. 1997.

[22] Standard Practice for Quantitative Measurement and Reporting of Hypoeutectoid Carbon and Low-Alloy Steel Phase Transformations,
ASTM. Committee A01 on Steel, Stainless Steel and Related Alloys. March 2004.

[23] J. Opara, A. Wrożyna. Development and validation of a quantitative dilatometric analysis model of austenite decomposition into ferrite and pearlite. Prace Instytutu Metalurgii Żelaza, 2015, 67 (4), p. 24-32.

[24] J. Opara, A. Wrożyna. Zastosowanie metody automatów komórkowych do opracowania cyfrowej reprezentacji wybranych cech mikrostruktury w oparciu o obrazy binarne jej składników. Prace Instytutu Metalurgii Żelaza, 2013, 65 (4), p. 2-7.

[25] H. Springer, M. Belde, D. Raabe. Bulk combinatorial design of ductile martensitic stainless steels through confined martensiteto-austenite reversion. Materials Science \& Engineering A, 2013, 582, p. 235-244.

[26] B.B. He, M.X. Huang. Revealing heterogeneous C partitioning in a medium $\mathrm{Mn}$ steel by nanoindentation. Materials Science and Technology, 2017, 33, p. 1-7.

[27] E. Gamsjäger, H. Chen, S. van der Zwaag. Application of the cyclic phase transformation concept for determining the effective austenite/ferrite interface mobility. Computational Materials Science, 2014, 83, p. 92-100.

[28] M. Pietrzyk, J. Kusiak, R. Kuziak, L. Madej, D. Szeliga, R. Gołą. Conventional and Multiscale Modeling of Microstructure Evolution During Laminar Cooling of DP Steel Strips. Metallurgical and Materials Transactions A, 2014, 45, p. 5835-5851. 